\title{
The Effects of Critical Success Factors on Social Enterprises Sustainability
}

\author{
Kanchaya Chaivirutnukul $^{1 *}$ and Achara Chandrachai ${ }^{2}$ \\ ${ }^{1}$ Technopreneurship and Innovation Management Program, Chulalongkorn University \\ Bangkok, Thailand \\ ${ }^{2}$ Faculty of Commerce and Accountancy, Chulalongkorn University \\ Bangkok, Thailand \\ *Corresponding author's email: a_art2000 [AT] hotmail.com
}

\begin{abstract}
This is a mix-method study to investigate critical success factors which can support social enterprises in Thailand to measure their sustainability. The quantitative data were gathered through questionnaire, while qualitative data were derived from semi-structures interview. The data were analyzed by descriptive statistics, a multiple regression, and content analysis. It was found that the highest-correlated factor with sustainable growth for social enterprises is Value Creation with mean value of 4.03. Importantly, Value Creation and The Philosophy of Sufficiency Economy were found to be the important indicators of economic, social, and environmental key performance, while Financial Management was the indicator of economic and environmental key performance of social enterprises in Thailand. The implications of this study shed light on how social enterprises make themselves sustainable and how they measure their sustainability over the long term.
\end{abstract}

Keywords-Social enterprises, critical success factors, social enterprises sustainability, economic key performance, social key performance, environment key performance

\section{INTRODUCTION}

Social enterprises can be referred as the businesses organizations which primarily place important on social or environmental objectives (Iyengar, 2015). The social enterprises deliver benefits in a self-sustaining way by using their income to finance activities that generate social benefit. In other words, the social enterprises have special characteristics that fulfill both economic and social purposes at the same time. The social enterprises are important for economic growth since they attempt to improve social or environmental problems by applying good governance together with social knowledge and innovation. These social enterprises are sustainable and earn income from their goods and service. In addition, they may earn their revenues from reinvesting in their mission. The social enterprises seemed to be more sustainable than a nonprofit organization because the social enterprises do not rely only on charity or donation.

\section{How does social enterprise play role in Thailand?}

In Thailand, there has been an establishment of a special committee to promote social enterprises and to initiate a master plan. The essence of the master plan is to support better social welfare in the local community - a concept deemed essential toward sustainable economic development, social development and political development at the grass root level. Its primary objectives lie at better quality of lives and well-being of local citizens, higher income creation, improving public welfare together with relevant risk management (Jariyavidyanont, 2010). All of the benefits will in turn lead to less dependence on public mechanism. The Thai Social Enterprise defines social enterprise as an organization that gains revenue from sale of products or services with clear objectives in term of problem solution and development for community, society or environment without the exclusive target of maximizing profit to shareholders and business owners. Social enterprises must compose of some particular characteristics. Their production process and business operation along with the products and services must not create long term negative impacts to the community, public welfare and environment. In addition, they must have good governance and financial sustainability. A good portion of the retained earning must be reinvested to further meet the predefined objective or return to the community and customers. Besides, their format can be diverse; and they must utilize sufficiency economy philosophy. There are a variety of types and styles but for the sake of strategic planning, policies and strategies for social enterprise, it is divided into 6 main groups: 1) Network and Community Organization; 2) Public organizations; 3) Government and state enterprises; 4) New operator; 5) Private Business; and 6) 
Other.

Nowadays, it is challenging for social enterprises to not only create social value, which is not generated by commercial enterprises, but also pursue an economic purpose with limited resources and support. Social enterprises endeavor to achieve social performance as well as financial sustainability by generating profits. In some cases, the performance of social enterprises is understood as an aspect of the sustainability of social enterprises According to the responsibilities of social enterprises to maintain financial advantages or their profits together with addressing social and environment issues, there might be suggested path to assist them obtain both financial, social, and environmental sustainability. One of primary theoretical concepts is Critical Success Factors (CSF). The study of the differences between social enterprises and commercial enterprises (Austin, Stevenson \& Wei-Skillern, 2006), and the study on the principles of social enterprises (Mort, Weerawardena, \& Carnegie, 2003) are empirical studies which compare successful social enterprises and factors leading to changes in the community, politics, as well as economy as a whole. These factors focus on growing numbers of value creation, innovation, leadership, and organization restructuring. Therefore, it can be said that all of the above are the studies on Critical Success Factors (CSFs). CSFs are the significant variables that social enterprises must have to achieve sustainability. Critical success factors have been defined as "Those things that must be done if a company is to be successful" (Freund, 1988). It was entirely supported by Bullen and Rockart (1981), pointing out critical success factors as the "limited number of strategic in which results, if they are satisfying, will ensure the competitive performance of the organization". In addition, Freund (1988) stated that critical success factors must be important to achieve overall mission, articulate things that have to be done, applicable to all firms in the industry with akin objectives. Besides, critical success factors are the organization's resources, competence and qualification that create its sustainable competitive advantage on a particular market and are able to determine its future success (van Veen-Dirks \& Wijn, 2002). Therefore, it can be said that critical success factors are what let an organization be outstanding from others, and therefore to create strong and positive interactions with the market it functions on.

Therefore, this study aims to examine the levels of each critical success factor affecting the sustainability of social enterprises in Thailand and investigate the effect of critical success factors on economic performance, social performance, and environmental performance. According to these purposes, this study employs quantitative and qualitative methodology to answer two research questions:

1) What are the levels of critical success factors affecting the sustainability of social enterprises in Thailand?

2) Do critical success factors affect economic, social, and environmental performance of social enterprises in Thailand?

A research hypothesis is Ha1: There is at least one critical success factor affect economic performance, social performance, and environmental performance.

In the Introduction section, present clearly and briefly the problem investigated, with relevant references. The main results should be enunciated.

\section{THEORETICAL BACKGROUND OF SUCCESS FACTORS FOR SOCIAL ENTERPRISE SUSTAINABILITY}

\subsection{The resource-based view $(\mathrm{RBV})$}

The resource-based view (RBV) is an influential approach to achieving competitive advantage. It is applicable for determining the strategic resources with the potential to deliver comparative advantage to a firm. This theory has become important viewpoint which can be applied for making social enterprise sustainable since the persistent discussion of this theory focuses on valuable resources and its relation to a firm's sustained competitive advantage. According to the RBV, strategic resources are those valuable resources that are rare, difficult to copy and irreplaceable (Barney, 1991). The central assertation of RBV is that resource availability is important; and enterprises should consider their resources and capacity instead of focusing on cost reduction and product differentiation from competition will help the enterprises sustainable. Since resource availability is crucial, the enterprises should pay close attention to the organizations' resources for the sake of better competitive advantage. As Barney (1991) suggested, the primary characteristics of strategic resources that offer competitive advantages to the enterprise compose of 4 characters: 1) the resources must have value for the business and the competition (Valuable Resources); 2) the resources must be rare (Rare Resources); 3) the resources cannot be copied or require a very high cost to do so (Imitate Resources); and 4) the resources are irreplaceable (Non-substitutable Resources). Given the significances and influences toward different business operations within the organization and corporate strategy management, the components of RBV compose of business analysis, industry analysis and the competitive landscape. Moreover, RBV leads to better competitive advantage at time of rapid change (Collis \& Montgomery, 1995).

The concept of RBV influenced the researchers to investigate the critical success factors to measure performance of enterprises. As stated by Boyer, Creech, and Paas (2008) the successful social enterprise requires 8 critical factors namely 1) Leadership, 2) Partnership, 3) Clear innovation values, 4) Business plan and marketing, 5) Triple Bottom Line planning, 6) Short term and long-term benefit management, 7) Community participation and 8) Risk management. This seemed to be consistent with Wronka (2013), finding that the 10 critical factors affecting social enterprise success in Poland were 1) Strong leadership, 2) Motivation and determination of the employees, 3) Laws and regulations, 4) Innovation attractiveness, 
5) Management skills, 6) Personal characters in top class service delivery, 7) Effective co-operation with the public sector, 8) Social capital, 9) Community participation, and 10) Correct financial data collection and reports.

The research to explore social enterprise in Germany mentioned that the lack of clear management system could clearly create demotivation. Then, life and profile of social entrepreneur are significant specifications (Mauksch, 2012). In terms of success factors evaluation in establishing a thriving social enterprise in Scotland, the method that the social enterprise used to determine the factors towards enterprise's success were: 1) the value of the stakeholders which means that the social enterprise must be able to create noticeable value which should be communicated to them clearly ;2) internal business process which is referred to the ability to deliver the values to the stakeholders effectively and most efficiently; 3 ) innovation and learning which is viewed as the ability of social enterprise to create maximum significant intangible assets and 4) monetary resource which leads to finding good fund and safe business managing (Coburn \& Rijsdijk, 2010).

The research topics of ASEAN countries including Thailand mostly pertain to poverty and high unemployment rate which results from poor public welfare management. This give rise to social enterprise emphasizes on activities that create higher income to people and promote a sustainable development. According to Santos (2009), in addition to the basic factors, service provider and environmental management play an important role toward success (Kerlin, 2009). In Thailand, the Institutional Research and Evaluation Office, Excellent Business Management Corporation examined the role of local private corporate in attacking poverty and social inequality problems and found that the success of social enterprise mostly depends on the enterprises themselves, for example the enterprises' determinations. The entrepreneurs must have survival skills and are capable of overcoming problems and obstacles. Such problems and obstacles are the lack of underprivileged people database and complicated process of data request from the related public offices.

\subsection{Knowledge Management}

The corporate resources with RBV can cause problems to the competitors and increase the probability of higher corporate profit in the future. Tacit knowledge of employees is considered as an important resource. If an organization wishes to gain a sustainability, it must encourage internal knowledge transformation among the staff. The cumulative knowledge must be transferred (Kogut \& Zander, 1992). SECI Model is a widely accepted tool in the field of knowledge management. Nanoka and Takeuchi (1995) presents the concept which divides knowledge of human into two groups namely explicit knowledge and tacit knowledge. Explicit knowledge is searchable information that can be easily found. On the other hand, tacit knowledge is possessed by people and difficult to share. This means that explicit knowledge is knowledge which one can collaborate on the value and use of the knowledge, while tacit knowledge tends to be difficult to share with another person by writing it down or verbalizing it. Therefore, these types of knowledge especially the tacit knowledge is very important to organizations and the organizations need to help people better articulate their tacit knowledge. SECI Model can describe general knowledge transformation process and combine the two knowledge types to create a new one (Nonaka, 1991).

According to the Knowledge-Creation Company, at time of certain economic uncertainty, one thing that drives a firm to achieve competitive advantage over the competitors is effective internal knowledge management (Nonaka, 1991). When the market changes, technology expands, competition becomes more intense and products become out of dated within days, a successful company continuously creates new knowledge and applies it to the firm's technology and products. Knowledge inside of a person that can be transformed to organizational knowledge is considered most valuable. Knowledge transfer occurring at each individual is the primary process of a knowledge creation company. New knowledge occurs continuously at every level within firm and sometimes appears in an unexpected format.

Knowledge management through SECI Model stimulates a firm to create new mutual knowledge and lead to endless value creation within the organization. It leads to sustainable business growth. The concept creates a clear framework and identifies success factors for social enterprise sustainability in Thailand.

\subsection{The Philosophy of Sufficiency Economy}

Sufficiency economy philosophy is a concept that encourages everyone in the society to live and behave with a moderate practice especially in term of economic development. Sufficiency means moderate, being reasonable, necessity and immunity to all kinds of internal and external changes (Naipinit, Promsaka Na Sakolnakorn, \& Kroeksakul, 2014). It requires thoughtful applications of knowledge to plan on work procedures. At the same time, there must promote moral principles toward all citizens especially public servants, academic professors and businessmen in order that they live and behave based on good will and moral principles with proper knowledge, patience, diligence, awareness, wisdom and carefulness to be ready for rapid changes occurring in all aspects of life. It is always applicable and views the world as a never-stop-changing system. The goal is to survive oneself from crises for the sake of firm and sustainable development. Additionally, everyone can apply sufficiency economy philosophy in their daily life through moderate practice and sequential developing. The decision and activity process based on the moderate practice must rely on knowledge and moral principles that is 
1) Knowledge consists of knowledge in all related academic philosophy. The thinking process will apply knowledge and connect ideas in order to form a careful plan.

2) Moral principles consist of awareness, honesty and patience with use of wisdom to live one's life.

Things that can be expected from adopting sufficiency economy philosophy is a balanced and long-lasting development that is immune to all aspects of changes in economy, society, environment, knowledge and technology.

According to Khunthongjan (2018) the entrepreneurs are keen to 1) run their business with honesty and do not take advantages of the customers, the employees and the suppliers; 2) exploit materials and equipment economically and 3) produce high quality goods and services in line with the management capability. Supporting by Puntasen, Premchuen and Keitdejpunya (2003),which investigated sufficiency economy philosophy used by 6 industries: food industry, textile industry, plastic and rubber industry, metal and non-metal industry, machinery industry, and logistic industry. It was found that that the industries which survived through the crisis in 1997 possess business practice adopting nine principles of sufficiency economy philosophy: 1) using the proper and economical technology, 2) utilizing raw materials and equipment economically, 3) having the right economy of scale in line with management capability, 4) recruiting workforce, 5) focusing on long term profitability, 6) running the business with honesty and taking no advantages of the customers, the employees and the suppliers, 7) diversifying products and services to mitigate risks to revenue, 8) having a proper financial management, 9) responding to local market, domestic market, and global market in an timely manner

To sum up, the philosophy of sufficiency economy emphasizes on moderateness, reasonableness and selfimmunity. These components must base on the ground of wisdom and moral principles.

\section{THE EVALUATION OF ENTERPRISES SUSTAINABILITY}

In the past decade, the principle of Triple Bottom Line has been employed in performance evaluation for many companies. The Triple Bottom Line is defined as a balance of sustainability in three different aspects: economy, society and environment, representing the three pillars of corporate sustainability. It explicitly implies that a successful economy is not the only significant factor to assess long term corporate solution. That means a successful company should relate to the objective of fulfilling the needs of corporate stakeholders and these people should be accounted for any outcomes that would happen based on Triple Bottom Line. World-class organizations have realized that the degree of corporate success should rest on sustainable development and advancement aiming to improve significantly the quality of life of the people in the community.

Sustainable investment and social responsibility have captured attention from both domestic and international investors and institutions. The value investors are interested in business that is aware of its contributions toward the community and realize the connection between the social performance, environmental performance and financial performance. These values are important and lead the business to maintain consistent profit and long run business. However, it turns out that there is no single tool which is able to assess sustainability directly. Further, main differences of assessing sustainability involve some reasons. Firstly, different criteria have been employed at the start of the operation classifying different aspects from different points of views. Secondly, similar outcomes have been evaluated differently through consecutive logical reasoning. Next, dissents among stakeholders that a company should involve and evaluate the impacts toward the company should be brought into consideration. Moreover, the approaches that the earlier evaluating tools assessed degree of success of corporate sustainability are not enough to set a foundation for the performance evaluation system. With this sort of context, sustainability assessment will be developed toward objectives and real values.

\section{RESEARCH METHODOLOGY}

\subsection{Population and Sample}

This study was conducted among all 401 social enterprises in Thailand (Social Enterprise Master Plan, 2010). Among these, 33 of them were social enterprises founded by new entrepreneurs and individuals, while 368 of them were founded by community enterprises or networks. For conducting quantitative section, questionnaires were sent to the social enterprises and they were completed by executives, directors, managers, or leaders of them. For conducting qualitative section, five social enterprises were selected purposively according to their high performance and the accessibility of them. They were social enterprises which could be representatives of all social enterprises from various types of business (their profiles are available in Appendix A). Moreover, these five social enterprises had been operating for more than 20 years in order to ensure that they may be sustainable firms.

\subsection{Instrumentation}

The questionnaire items were combined from review of literature and semi-structured interviews of purposively-selected social enterprises. The questionnaire consisted of 69 questions. In order to improve the validity by using Index of ItemObjective Congruence (IOC), the questionnaire items were reviewed by five specialists on social enterprise and research study. The IOC values showed that the questionnaire items were appropriate to use for this study. In addition, the questionnaire was tested the reliability by using Cronbach's alpha. The questionnaire was sent to 30 social enterprises to 
calculate the confidence levels of the interview questions and the overall alpha-coefficient of factor was 0.917 , higher than 0.70, indicating a highly reliable instrument (Mohajan, 2017).

For conducting qualitative section, the researcher employed semi-structured interview which comprised of 11 questions which were designed in such a way that interviewees could input their thoughts on what critical factors relating to sustainable growth of social enterprises must be.

\subsection{Data collection}

In the quantitative section, the questionnaires were sent to all 401 social enterprises by mails, e-mails and hands depending on their convenience. The responses were followed up until it reached $100 \%$. The period of data collection took approximately 6 months.

In the qualitative section, the researcher made appointments with five social enterprises with prior notification on objectives and research details. Each social enterprise then selected its own interviewees. An interview took about 2 hours and was allowed for a sound record.

\subsection{Data analysis}

In order to answer research question 1, the data were analysed by descriptive statistics. In addition, a multiple linear regression was employed to analyse data for examining research question 2 . The independent variables were seven factors influencing sustainable growth of social enterprises: 1) Value creation ,2) Leadership, 3) Stakeholders engagement, 4) The philosophy of sufficiency economy, 5) Innovation management, 6) Knowledge management, 7) Financial management. The dependent variables were economic key performance, social key performance, and environment key performance. The qualitative data were analysed by content analysis.

\section{RESULTS}

Since it is important to confirm that all firms were characterized as social enterprises, the researchers provide basic questions on social enterprise activities to capture basic information and types of business operations in the first section of the questionnaire. It might be accepted that all 401 social enterprises had the characteristics of social enterprises (see Table 1).

Table 1: Numbers of social enterprises for each activity

\begin{tabular}{|c|c|c|}
\hline Item & Format of Business Operations & $\begin{array}{c}n=401 \\
\text { Percentages } \\
\text { Yes }\end{array}$ \\
\hline 1 & Activities can generate income to business. & 100 \\
\hline 2 & Activities spends parts of their profit to benefits the community. & 99.75 \\
\hline 3 & Activities are environmentally friendly and do not damage nature. & 99.75 \\
\hline 4 & Activities drives innovation and knowledge. & 98.75 \\
\hline 5 & Activities improve the quality of lives within the community. & 98.50 \\
\hline 6 & $\begin{array}{c}\text { Activities founded by the participation of the stakeholders, who are communities, business suppliers, } \\
\text { business partners, or staffs. }\end{array}$ & 92.02 \\
\hline 7 & Activities have connections with both state-own enterprises and private sector. & 92.02 \\
\hline 8 & Activities create jobs in the community for the unemployed and the handicaps. & 90.02 \\
\hline 9 & Activities are sustainable without external funding. & 88.03 \\
\hline
\end{tabular}

As it was seen from Table 1, the most common form of social enterprises is the activities that generate income (accounted for $100 \%$ ). The second most common form is the activities that spend part of the profit to benefit the community and the activities that are environmentally friendly (accounted for 99.75\%). The least common form of social enterprises are the activities that sustainable without external funding. (accounted for 88.03\%). The results were reported following according to research questions.

\subsection{The levels of critical success factor}

RQ 1) What are the levels of critical success factors affecting the sustainability of social enterprises in Thailand?

To answer research question 1 , the seven critical success factors which relate to the sustainability of social enterprises in Thailand including Value Creation, Leadership, Stakeholders Engagement, The Philosophy of Sufficiency Economy, Innovation Management, Knowledge Management, and Financial Management were analysed by descriptive statistics. Mean and standard deviation values were reported in Table 2. 
Table 2: Means and standard deviations of factors influencing to sustainable social enterprises growth.

\begin{tabular}{c|c|c|c}
\hline No & Factors relating to sustainable social enterprises growth & $\bar{x}$ & S.D. \\
\hline 1 & Value Creation & 4.03 & 0.54 \\
2 & Leadership & 3.98 & 0.49 \\
3 & Stakeholders Engagement & 3.98 & 0.48 \\
4 & Sufficiency Economy & 3.87 & 0.48 \\
5 & Innovation Management & 3.84 & 0.53 \\
6 & Knowledge Management & 3.79 & 0.46 \\
7 & Financial Management & 3.69 & 0.72 \\
\hline \multicolumn{2}{r|}{} \\
\hline
\end{tabular}

According to Table 2, it is found that seven factors contributing to high sustainable growth in social enterprises has overall mean values of 3.88. Specifically, the factor with the highest correlation with sustainable growth in social enterprises is Value Creation with mean value of 4.03, followed by Leadership and Stakeholders Engagement with mean value of 3.98. The least-relating factor is Financial Management with mean value of 3.69.

Descriptive statistics above showed that social enterprises in Thailand obtained high levels of all seven critical factors (more than 3.5 points out of 5). This means, the social enterprises viewed that all seven critical factors are important and helpful for business sustainability as they stated from the interview section as followed:

\section{The 1st Factor: Value Creation}

Social enterprises should be oriented toward product and services development so as to maintain their high-quality standard, to prevent harm to customers, and to make sure that the organization is maintaining fair moral ground. Social enterprises should adequately reveal accurate and up-to-date product and services information while at the same time do not disclose any private information of the customers to seek their own benefits or commercial exploitation. Social enterprises should concern the impacts of their products to the environment as well as their safety to consumers in all stages. Therefore, all the resources used for the social enterprises should be efficiently utilized and improving the quality of lives, economic wealth, and also supporting creativities within the communities, so that they can further create new innovation to businesses and the society.

\section{The 2nd Factor: Leadership}

Organization leaders emerge as highly respectable figures among group members and from direct official designation. Efficient leaders need to have strong leadership together with good management skills especially in today's world that we apparently need leaders who have great vision and are able to create inspirations among the group members, so that they can drive the organization toward the right direction and achievement. Good leaders must be good role models to the followers. They should understand problems that arise and help members to fix the problems. Friendly leaders tend to have a wide network to support their job in term of policies and principles. Leaders who gain respects and trusts from many different outside parties can be deemed as advantages for the organization, in a sense that they can lead to higher chances for gaining more supports and aids from other entities because if otherwise it can be difficult to achieve.

\section{The 3rd Factor: Stakeholders Engagement}

The stakeholders will provide us with the understandings and ability to build balanced strategies as to suitably serve the needs and expectations from different groups of people. To communicate and to pay attention to the stakeholders helps to strengthen relationships as well as to create effective operations within the organizations. Moreover, social enterprises should be able to adapt the processes in establishing long term relationships appropriate to the right group of stakeholders, through various channels or different means of communications. Social enterprises with clear policy framework can help people coordinate with other organizations smoothly. In addition, by upholding transparency and equality within the organization will help the entity able to answers questions from others.

\section{The 4th Factor: Sufficiency Economy}

The management team who has adopted the concept of sufficiency economy will help them run the business with good rationales, bring insights from the customers, the market, and their own business, as well as help their staffs to attain better moral ethics. Adopting the concept above can be seen as an approach to prevent the business from facing with the operational risk while improving their skills in coordinating with others. This will help the business gain sustainable benefits in the long-run and help the economy grow stably.

\section{The 5th Factor: Innovation Management}

Social enterprises should develop the ideas and procedures that are linked together in order to grow their business. In the early stage, social enterprises can create an innovation within the organization by just adapting new ideas from their own staff or from outsiders. This way there is no need for the organization to start doing the whole research by itself. All 
they need to do are just catching up with new ideas, new knowledge, and new trends, in order to grow successfully, while also being able to fulfil their customers' needs which keep changing all the time.

\section{The 6th Factor: Knowledge Management}

Social enterprises should manage available knowledge retrieved from their personnel or documents by developing them into a system so that everyone in the organization can access to these knowledges and use them to upgrade themselves to become experts and operate their jobs more efficiently. This in turn will boost their competitiveness to the highest. Apart from the knowledge accessibilities and the knowledge upgrades, the methods of knowledge transfer are also important. There are many forms of knowledge transfer such as job seminars among colleagues, new staff orientation and so on. In addition, the knowledge transfer can be in the form of computer technology as in their intra-network that in the end can manage all knowledge and help the organization become more efficient and innovative.

\section{The 7th Factor: Financial Management}

Social enterprises must set up an operation responsible for getting capital funding from different sources and efficiently managing administrative cost. They should also make sure that the businesses have adequate fund to operate in the longrun. The capital must be appropriately utilized upon professional investment standards and the interests from every transaction should be collected as expected. Capital controller has to perform financial planning for the internal organization. They need to be prudent and being equipped with good skills on detecting accuracy. They must study from the mistakes made so that the next financial planning can be improved thereafter.

In order to investigate factors which were appropriate to measure economic, social, and environmental sustainability of social enterprises, the results of a multiple regression were described in the next section.

\subsection{The effect of critical success factors on economic, social, and environmental performance}

RQ 2) Do critical success factors affect economic, social, and environmental performance of social enterprises in Thailand?

In this process, a multiple linear regression analysis was employed to investigate the predictors of social enterprises sustainability. A multiple linear regression analysis is a tool to study the relationship between many independent variables and a single dependent variable, with the aim to find out which independent variables are able to predict, forecast, or explain the variation of the dependent variables (Pandis, 2016). The factors affecting the efficiency of social enterprises included leadership, stakeholder engagement, value creation, innovation management, financial management, knowledge management and sufficiency economy. There were three dimensions of social enterprises' sustainability: economic sustainability, social sustainability, and environmental sustainability. The results of a multiple linear regression analysis were shown in Table 3-5.

Table 3 The effect of critical success factors on economic performance

\begin{tabular}{c|c|c|c}
\hline Factors & beta & T & Sig. \\
(Constant) & & 6.179 & .000 \\
\hline Financial management & .288 & 5.143 & .000 \\
Value creation & .264 & 3.888 & .000 \\
\hline The philosophy of sufficiency economy & .220 & & \\
\hline
\end{tabular}

From Table 3, it is found that there are three critical success factors influencing on economic sustainability of social enterprises: Financial Management $(\mathrm{P}<0.01$, beta $=0.288)$, Value Creation $(\mathrm{P}<0.01$, beta $=0.264)$, and The Philosophy of Sufficiency Economy $(\mathrm{P}<0.01$, beta $=0.220)$. The beta values indicate that the most influencing factor of economic sustainability was Financial Management (beta $=0.288)$.

Table 4 The effect of critical success factors on social performance

\begin{tabular}{c|c|c|c}
\hline $\begin{array}{c}\text { Factors } \\
\text { (Constant) }\end{array}$ & beta & T & Sig. \\
\hline The philosophy of sufficiency economy & .398 & 7.256 & .000 \\
Value creation & .219 & 3.987 & .000 \\
\hline
\end{tabular}

From Table 4, it is found that there are two critical success factors influencing on social sustainability of social enterprises: The Philosophy of Sufficiency Economy $(\mathrm{P}<0.01$, beta $=0.398)$ and Value Creation $(\mathrm{P}<0.01$, beta $=0.219)$. The beta values indicate that the most influencing factor of social sustainability was The Philosophy of Sufficiency Economy (beta $=0.398)$. 
Table 5 The effect of critical success factors on environmental performance

\begin{tabular}{c|c|c|c}
\hline Factors & beta & T & Sig. \\
(Constant) & & & \\
\hline The philosophy of sufficiency economy & .338 & 5.403 & .000 \\
Value creation & .139 & 2.455 & .015 \\
Financial management & .137 & 2.670 & .008 \\
\hline
\end{tabular}

From the table 5, it is found that there are three critical success factors influencing on environmental sustainability of social enterprises: The Philosophy of Sufficiency Economy $(\mathrm{P}<0.01$, beta $=0.338)$, Value Creation $(\mathrm{P}<0.05$, beta $=0.139)$ and Financial Management $(\mathrm{P}<0.01$, beta $=0.137)$. The beta values indicate that the most influencing factor of environmental sustainability was The Philosophy of Sufficiency Economy (beta $=0.338$ ).

To sum up, an alternative hypothesis of this study (Ha1: There is at least one critical success factor affect economic performance, social performance, and environmental performance.) was accepted.

\section{DISCUSSION AND CONCLUSION}

\subsection{The effect of critical success factors on economic performance}

Three factors indicating economic sustainability of social enterprises in Thailand include Financial Management, Value Creation, and The Philosophy of Sufficiency Economy.

It was not surprising that Financial Management is considered as a significant indicator toward economic sustainability of social enterprises in Thailand. It is in line with Salikin, Ab Wahab, \& Muhammad, 2013) who found that financial management is the most important factor for SMEs. If a company can operate without seeking external funding sources, it means that the business has good financial management. Nonetheless for a growing business, it is necessary for the entrepreneurs to increase business investment in order to support customer demand. Employing knowledgeable staff will overcome the limitation in term of securing external funding through prudential accounting and financial management.

The contribution of Value Creation is in line with Makkonen and Sundqvist-Andberg (2017) who found that facilitating their essential customers by building value creation will be considered as one of the criteria for a long-term success of social enterprises. Recently, the needs of the target customers are in a wider range and going beyond just only the characteristics of the products or efficiency in production line. Therefore, social enterprises need to focus on building value creation regularly and continuously for their customers. Moreover, social enterprises also need other units or businesses in the value chain to add values for their customers, by which these increasing economic values will be eventually transformed into a cashflow or trade benefits and helped social enterprises to grow sustainably (Strothotte \& Wüstenhagen, 2005).

The claim that The Philosophy of Sufficiency Economy was considered to be an important indicator toward economic sustainability of social enterprises in Thailand is parallel with Phanthasaen, Premchuen, and Kiatdechapanya (2002) who found the benefits from gradual business expansion, in a sense that we will apply for a loan on material purchase by using only a profit margin to expand the business, which is taken as a moderate path to operate the business sensibly. The philosophy of sufficiency economy is the real element for the entrepreneurs to use in reality, which have helped some of them to survive through 1997 Thai Financial Crisis. Some of those successful entrepreneurs have gotten the awards to guarantee their performances in following the philosophy of sufficiency economy (Khunthongchan, Phantasen, and Vibulphong, 2010).

\subsection{The effect of critical success factors on social performance}

The Philosophy of Sufficiency Economy was found to be an important indicator of social sustainability. Areekul (2013) stated that social capital has regularly been mentioned about. As by the style of living and the culture of Thai society, they need to apply Thai traditional knowledge, skills, beliefs, or wisdoms with modern technology, in order to develop their community. Their aims are for the business activities in their community to have greater effectiveness and efficiency, which are in line with the condition of success in using the social capital to grow sustainable development in the community. Those condition are to use the philosophy of sufficiency economy to create a community business that is not dependent on the outside units, as well as being ready and determined to rely on themselves before asking for helps from outsiders.

The claim that Value Creation affect social sustainability of social enterprises may happen only when the business creates values that are useful for all of their stakeholders (Laszlo,2008). When companies design a new factory, they may plan to use less energy, for both creating heat or lights, and also to use less construction capital than what other factories do. It helps to create sustainability in growth for that company. Moreover, the companies also limit packaging disposals by adjusting the sizes of the packaging to fit with the sizes of their products. They may use the product materials that can be recycled, reused, and decomposed naturally, with less toxics to the environment. In the end, the social enterprises will be able to make profits from serving society needs that have never been found. For example, a company can provide hygienic drinking water for the poor people, which is consistent with the company concept to develop and build values to social 
welfares and also to people in their society for creating sustainable growth to the society, apart from meeting the company's goals (Sharma, 2003).

\subsection{The effect of critical success factors on environmental performance}

With the growing globalization of social and economic activities, environmental issues become a fundamental component of the new business playing field (Michel-Kerjan, 2014). Hence, to gather factors affecting environmental sustainability is somewhat important for current situation of firms. The Sufficiency Economy Philosophy was considered to be an important indicator toward environmental sustainability of social enterprises in Thailand. Since the model of sufficiency economy promotes moderation and sustainable step-by-step development with environmental considerations by being a proper sync and balance (Shone 2011). From coordinating with business operations, farmers or local people are able to sell their natural products mand their income may gradually increase. At the same time, the environment is respected and protected as well as the family institution and community are strengthened. Coming from Thai context, the researchers have learned that the sufficiency economy model enhance people to concern for importance environment and preserve the natural sources for community. Therefore, this factor will undoubtedly related environmental suitability.

The second indicating factors for environmental sustainability was Value Creation. Firms aim to satisfy customer needs better than their competitors (Day, 1994, as cited in Gummerus, 2013), and this is purportedly reflected in higher value for the customers (Gummerus, 2013). Then, the firms will create to add higher value to their products and services as well as to make customers satisfy. As being Thai customers, the researchers perceived that the current trends of customers may concern for preserving natural resources or environment. If there were two choices of the same product, one is produced from environmentally friendly materials, another is produced from non-environmentally unfriendly, the customers probably choose the former one - green products. For this point of view, value creation may be partly related to environmental concerns. Therefore, Value creation could predict environmental key performance.

The final indicating for environmental sustainability was Financial Management. This is parallel with LaSalle (2008) who proposed that finance executives mentioned that finance plays a substantial role in the environmentally conscious investment of company assets. If the firms manage their finance well, it may lead them to be more sustainable environment.

To sum up, it was seen that The Sufficiency Economy Philosophy and Value Creation influenced on economic, social and environmental sustainability, while Financial management influenced on economic and environmental sustainability. It is undoubtedly saying that The Sufficiency Economy Philosophy was an important factor for social enterprises' sustainability as it was revealed that it influences on all three dimensions: economic, social, and environmental sustainability.

\section{LIMITATION AND RECOMMENDATIONS}

The limitation of this study was the accessibility on survey process. Since the details of social enterprises in Thailand may be collected unsystematically, the accessibility to them were rather difficult.

The recommendation for social enterprises improvement is that the social enterprises should realize the indicating factors for economic, social, and environmental sustainability revealing from this study. It may help the firms to measure the level of their performance and find the way to be long-running firms.

The recommendation of further research is that it may be interesting to analyse factors contributing to social enterprise sustainability according to business life cycle in the future.

\section{APPENDIX}

\section{Social Enterprise A}

Enterprise A is a private school which operates as a non-profit enterprise and is taken cared by a Principal. The enterprise aims to have a holistic learning for the students; therefore, the school environment emphasizes on its objective on encouraging the students in each stage to integrate learning by themselves. The classrooms, buildings and environment has been designed to support students' learning for both inside and outside of the classrooms. The school conducts field trips for the students to learn through direct experience. In terms of food, the school focuses on nutrition. In addition, the school ids equipped in providing additional learning tools and textbooks. Social Enterprise A believes that creating warm environment within the learning community will nurture the community towards sustainability.

\section{Social Enterprise $B$}

Social Enterprise B is a Television Program Producer producing programs which benefit the society as these focus on providing knowledge for people in general. The enterprise was founded on the idea of responsible mass media with the objective to produce television programs that have useful content and enables viewers to reflect on problems and solutions 
as well as creating awareness in terms of society, community, environment, culture, sustainable agriculture, ethnic diversity, health, academic progress and science. This advocacy helps the society as a whole in providing useful information for people's daily life. The aim of Social Enterprise B does not only focus on benefits of the business, but to provide useful information which will be beneficial for social awareness and responsibility. The quality of programs must adhere to certain standards so with the quality of life of every employee in the company.

\section{Social Enterprise $C$}

Social Enterprise $\mathrm{C}$ is a private sector development organization working as a marketing function to connect the farmers in the market network, connects the community businesses with the consumers focusing on supporting and introducing organic farming. It develops marketing strategies and alternatives to create participation from both producers and consumers, encouraging the producers to adapt to organic processes of farming which later on produce natural products which are safe for the consumer's health at the same time protects the environment from chemical procedures. They also ensure the quality of these products as they operate as distributor by initiating Distribution Centre which displays the different organic products such as rice, grains, vegetables, fruits, herb tea, processed food including local weaving textiles that are environment-friendly.

\section{Social Enterprise D}

Social Enterprise D is a private non-profit organization operating since 1974. The enterprise is committed to help the less marginalized people improve in their quality of life. The organization works on almost 300 different projects. The activities that they give more importance are: family planning, primary health care, natural resources and environment conservation, providing understanding on AIDS, democracy enhancement, competency development for woman and child, scholarship for every education level, safe drinking water, water resource for domestic houses and water for agriculture development, occupational and income development, industry expansion to create income for people in upcountry areas, also to reduce relocation and build strength for family and community. According to the strategy and operating method, the result can be seen clearly and can be applied to different areas not only within the country, but also to adjacent countries and other continents that find this advocacy helpful and effective.

\section{Social Enterprise E}

Social Enterprise $\mathrm{E}$ is a hospital institution that has been working on herbal medicine to be incorporated with the modern technological medical processes. The organization is dedicated to herb development for a long time. It aims to inherit Thai herb wisdom by acting as the bridge connecting between traditional wisdom and the new generation medical approach in order to bring back the glorious role of the herbs as medicinal cure. The institution aims to combine pharmaceutical technology and science research as well as inculcating local botanical knowledge as learned from ancient doctors which has been found helpful for a long time in the place. In addition, Thai Traditional and Alternative Medicine service have been developed through the years such as massage therapy and health check-up by Thai Traditional Medicine doctor. The hospital provides advices and suggestions related to health care and herbs. This service of the hospital is to encourage the nation's self-sufficiency in terms of medicines, reducing the trade balance of imported medicine and enhancing environmental sustainability in order to provide good and sustainable way of life for people in the society.

\section{REFERENCES}

[1] Areekul, C., "Model Development for Strengthening Social Capital for Being a Sustainable Lifelong Learning Society", PhD Dissertation, Department of Non-Formal Education, Faculty of Education, Chulalongkorn University, Thailand, 2013.

[2] Austin, J., Stevenson, H. and Wei-Skillern, J., "Social and Commercial Entrepreneurship: Same, Different, or Both?", Entrepreneurship Theory and Practice, vol. 30, no.1, 2006.

[3] Barney, J., "Firm Resource and Sustained Competitive Advantage”, Journal of Management, vol. 17, no. 1, pp. 99-120, 1991.

[4] Bullen, C.V. and Rockart, J.F., A Primer on Critical Success Factors, Massachusetts Institute of Technology, Sloan School of Management, Massachusetts, USA, 1981.

[5] Coburn, J. and Rijsdijk, R., "Evaluating the Success Factors for Establishing a Thriving Social Enterprise in Scotland", Social Science in Government, 2010.

[6] David, C. and Montgomery, C.A., "Competing on Resources: Strategy in the 1990s”, Harvard Business Review, vol. 73 (July-August), pp.118-128, 1995.

[7] Essen, J., "Sufficiency Economy and Santi Asoke: Buddhist Economic Ethics for a Just and Sustainable World”, Journal of Buddhist ethics, 2010.

[8] Freund, Y.P., “Critical success factors' Planning Review”, vol. 16, no. 4, 1988. 
[9] Gummerus ,J., "Value creation processes and value outcomes in marketing theory: Strangers or siblings?”, Marketing Theory, vol. 13, no. 1, 2013.

[10] Iyenger, A., "Role of Social Enterprise Greenhouse in Providence's Economic Development", Social Enterprise Greenhouse Talent Retention Intern, 2015.

[11] Jariyavidyanont, S., "Social Entrepreneurship: Principles and Basic Concepts for Social Development", Journal of Social Development, vol. 12, no.1, 2010.

[12] Kerlin, J.A., Social enterprise: A global comparison, University Press of New England, 2009.

[13] Khunthongjan, S., "Increasing labor productivity of non-vocational graduates in happy-workplace organizations", Silpakorn University Journal, vol. 38, no. 4, 2018.

[14] Kogut, B. and Zander, U., "Knowledge of the Firm, Combinative Capabilities, and the Replication of Technology", Organization Science, vol. 3, no. 3, 1992.

[15] LaSalle, J.L., "The Role of Finance in Environmental Sustainability Efforts”, CFO Publishing Corp., Boston, 2008.

[16] Makkonen, M. and Sundqvist-Andberg, H., "Customer value creation in B2B relationships: Sawn timber value chain perspective", Journal of Forest Economics, 29, 2017.

[17] Michel-Kerjan, E.O., Environmental Sustainability and value Creation, 2014.

[18] Mohajan, H., "Two Criteria for Good Measurements in Research: Validity and Reliability", Annals of Spiru Haret University, vol. 17, no. 3, 2017.

[19] Mort, G.S., Weerawardena, J. and Carnegie, K., “Social Entrepreneurship: Towards Conceptualisation”, International Journal of Nonprofit and Voluntary Sector Marketing, vol. 8, no. 1, 2002.

[20] Naipinit, A., Promsaka Na Sakolnakorn, T. and Kroeksakul, P., "Sufficiency Economy for Social and Environmental Sustainability: A Case Study of Four Villages in Rural Thailand”, Asian Social Science, vol. 10, no. $2,2014$.

[21] Nonaka, I., "The Knowledge Creating Company”, Harvard Business Review, vol. 69, pp. 96-104, 1991.

[22] Pandis, N., "Multiple linear regression analysis", American Journal of Orthodontics and Dentofacial Orthopedics, vol. 149, no. 4, 2016.

[23] Puntasen, A.,Premchuen, S. and Keitdejpunya, P., Application of the royal thought about the Sufficiency Economy in SMEs, Bangkok: Thailand Research Fund, 2003.

[24] Salikin, Ab Wahab and Muhammad, "Strengths and Weaknesses among Malaysian SMEs: Financial Management Perspectives", Paper Presented at the International Conference on Innovation, Management and Technology Research, 22-23 September 2013, Malaysia, 2013.

[25] Shin, C., "How Social Entrepreneurs Affect Performance of Social Enterprises in Korea: The Mediating Effect of Innovativeness", Sustainability, vol.10, no. 8, 2018.

[26] Shone, J.J., "National Sustainable Development Policy under the Approach of the Sufficiency Economy Philosophy: A Case Study of the LAO P.D.R.”, Unpublished PhD Dissertation, Chulalongkorn University, Thailand, 2011.

[27] Strothotte, T.G. and Wüstenhagen, R., "Structure of Sustainable Economic Value in Social Entrepreneurial Enterprises", in G.T. Vinig, R.C.W. Van Der Voort (ed.), The Emergence of Entrepreneurial Economics, Emerald Group Publishing Limited, pp.129 - 140, 2005.

[28] Suntrayuth, S., "The Sufficiency Economy Philosophy and Small and Medium-sized Enterprises in Thailand", International Review of Management and Marketing, Econjournals, vol. 8, no. 2, 2018.

[29] van Veen-Dirks, P. and Wijn, M., "Strategic control: meshing critical success factors with the balanced scorecard", Long Range Planning, vol. 35, no. 4, 2002.

[30] Weerawardena, J., Mcdonald, R.E. and Mort, G.S., "Sustainability of nonprofit organizations: An empirical investigation", Journal of World Business, vol. 45, no. 4, 2010. 